University of Nebraska - Lincoln

DigitalCommons@University of Nebraska - Lincoln

Nebraska Cooperative Fish \& Wildlife Research Nebraska Cooperative Fish \& Wildlife Research Unit -- Staff Publications

2012

\title{
Species, Functional Groups, and Thresholds in Ecological Resilience
}

Shana M. Sundstrom

University of Calgary, sundstrom.shana@gmail.com

Craig R. Allen

USGS Nebraska Cooperative Fish and Wildlife Research Unit, University of Nebraska, callen3@unl.edu

Chris Barichievy

University of the Witwatersrand

Follow this and additional works at: https://digitalcommons.unl.edu/ncfwrustaff

Sundstrom, Shana M.; Allen, Craig R.; and Barichievy, Chris, "Species, Functional Groups, and Thresholds in Ecological Resilience" (2012). Nebraska Cooperative Fish \& Wildlife Research Unit -- Staff Publications. 106.

https://digitalcommons.unl.edu/ncfwrustaff/106

This Article is brought to you for free and open access by the Nebraska Cooperative Fish \& Wildlife Research Unit at DigitalCommons@University of Nebraska - Lincoln. It has been accepted for inclusion in Nebraska Cooperative Fish \& Wildlife Research Unit -- Staff Publications by an authorized administrator of DigitalCommons@University of Nebraska - Lincoln. 


\title{
Species, Functional Groups, and Thresholds in Ecological Resilience
}

\author{
SHANA M. SUNDSTROM, ${ }^{*}$ C CRAIG R. ALLEN, †† AND CHRIS BARICHIEVY \\ *Faculty of Environmental Design, University of Calgary, 2500 University Drive NW, Calgary, Alberta T2N 1N4, Canada \\ ††U.S. Geological Survey, Nebraska Cooperative Fish \& Wildlife Research Unit, 423 Hardin Hall, School of Natural Resources, \\ University of Nebraska, Lincoln, NE 68583-0984, U.S.A. \\ $\ddagger$ Centre for Water in the Environment, School of Animal, Plant and Environmental Sciences, University of the Witwatersrand, \\ Johannesburg 2050, South Africa
}

\begin{abstract}
The cross-scale resilience model states that ecological resilience is generated in part from the distribution of functions within and across scales in a system. Resilience is a measure of a system's ability to remain organized around a particular set of mutually reinforcing processes and structures, known as a regime. We define scale as the geographic extent over which a process operates and the frequency with which a process occurs. Species can be categorized into functional groups that are a link between ecosystem processes and structures and ecological resilience. We applied the cross-scale resilience model to avian species in a grassland ecosystem. A species' morphology is shaped in part by its interaction with ecological structure and pattern, so animal body mass reflects the spatial and temporal distribution of resources. We used the logtransformed rank-ordered body masses of breeding birds associated with grasslands to identify aggregations and discontinuities in the distribution of those body masses. We assessed cross-scale resilience on the basis of 3 metrics: overall number of functional groups, number of functional groups within an aggregation, and the redundancy of functional groups across aggregations. We assessed how the loss of threatened species would affect cross-scale resilience by removing threatened species from the data set and recalculating values of the 3 metrics. We also determined whether more function was retained than expected after the loss of threatened species by comparing observed loss with simulated random loss in a Monte Carlo process. The observed distribution of function compared with the random simulated loss of function indicated that more functionality in the observed data set was retained than expected. On the basis of our results, we believe an ecosystem with a full complement of species can sustain considerable species losses without affecting the distribution of functions within and across aggregations, although ecological resilience is reduced. We propose that the mechanisms responsible for shaping discontinuous distributions of body mass and the nonrandom distribution of functions may also shape species losses such that local extinctions will be nonrandom with respect to the retention and distribution of functions and that the distribution of function within and across aggregations will be conserved despite extinctions.
\end{abstract}

Keywords: biodiversity, cross-scale resilience, endangered species conservation, functional groups, grassland, regime shifts

Especies, Grupos Funcionales y Umbrales en Resiliencia Ecológica

Resumen: El modelo de resiliencia transescala establece que la resiliencia ecológica se genera en parte por la distribución de funciones dentro y a través de escalas en el sistema. La resiliencia es una medida de la habilidad de un sistema para permanecer organizado en torno a un conjunto determinado de procesos y estructuras mutuamente reforzadoras, conocido como régimen. Definimos escala como la extensión geográfica en la cual opera un proceso y la frecuencia con que ocurre. Las especies se pueden clasificar en grupos funcionales que

\Current address: Nebraska Cooperative Fish \& Wildlife Research Unit, School of Natural Resources, University of Nebraska, Lincoln, NE 68583-0984, U.S.A, email sundstrom.shana@gmail.com

Paper submitted December 8, 2010; revised manuscript accepted July 22, 2011.

This article is a U.S. government work, and is not subject to copyright in the United States. 
son un vínculo entre los procesos del ecosistema y la resiliencia ecológica. Aplicamos el modelo de resiliencia transescala a especies de aves en un ecosistema de pastizal. La morfología de una especies esta determinada en parte por su interacción con la estructura y patrón ecológico, de tal modo que la masa corporal de un animal refleja la distribución espacial y temporal de los recursos. Utilizamos la masa corporal, ordenada por rangos y transformada logarítmicamente, de aves asociadas a pastizales para identificar agregaciones $y$ discontinuidades en la distribución de esas masas corporales. Evaluamos la resiliencia transescalar con base en 3 medidas: número total de grupos funcionales, número de grupos funcionales dentro de una agregación, y la redundancia de grupos funcionales en las agregaciones. Evaluamos el efecto de la pérdida de especies amenazadas sobre la resiliencia transescalar mediante la remoción de especies amenazadas del conjunto de datos y el nuevo cálculos de las 3 medidas. También determinamos si se retenía más función que lo esperado después de la pérdida de especies amenazadas mediante la comparación de la pérdida observada con la pérdida aleatoria simulada en un proceso Monte Carlo. La distribución observada de la función comparada con la pérdida aleatoria simulada indicó que se retenía mas funcionalidad que la esperada en el conjunto de datos observados. Con base en nuestros resultados, consideramos que un ecosistema con un complemento completo de especies puede sustentar considerables pérdidas de especies sin que se afecte la distribución de funciones dentro y entre agregaciones, aunque la resiliencia ecológica se reduce. Proponemos que los mecanismos responsables de moldear las distribuciones discontinuas de la masa corporal y la distribución no aleatoria de funciones también puede moldear la pérdida de especies, como extinciones locales, serán no aleatorios con respecto a la retención y distribución de funciones y que la distribución de la función dentro y entre agregaciones se conservará no obstante las extinciones.

Palabras Clave: especies, grupos funcionales, umbrales de la resiliencia ecológica

\section{Introduction}

Ecological processes and functions are maintained by the manner in which the functional roles of species are distributed within an ecosystem and by their differential responses to disturbances (Nystrom 2006). Primary productivity in grasslands and nutrient and energy fluxes in tropical rainforests may depend more on the functional role of species than on species richness, and the composition of species in functional groups may be more important to the resilience of ecological processes and functions than the number of functional groups (Silver et al. 1996; Hooper \& Vitousek 1997).

Functional groups pertain to biological diversity at the species level, which is useful because species have been the focus of study for many decades. As a result, the causes, patterns, and consequences of changes in species composition are relatively well known compared with other organizational levels of diversity (Chapin et al. 2000). Ecological functions are performed by vertebrate, invertebrate, and plant species in an ecosystem, and the nonrandom pattern of their distribution within and across the scales of an ecosystem is thought to contribute to ecological resilience (Peterson et al. 1998; Wardwell et al. 2008).

We define scale as the geographic extent over which a process operates and the frequency with which a process occurs. Ecological resilience is a measure of a system's ability to remain organized around a particular set of mutually reinforcing processes and structures (Holling 1973), known as a regime. For example, reefs are maintained in a hard-coral regime by the grazing of a few functional groups of herbivorous fishes (Bellwood et al. 2004). The intensive harvest of herbivorous fishes in Caribbean reefs led to increases in the abundance of sea urchins, which became the primary grazers. When extensive hurricane damage in 1980 was followed by a disease outbreak that greatly reduced the number of sea urchins, the reefs shifted to a macroalgae-dominated regime, which largely persists today (Hughes 1994; Mumby et al. 2007).

Alternative stable states, also known as regimes, have been documented in a wide variety of ecosystems (Folke et al. 2004), and a given regime may be less desirable if it provides fewer goods and services to humans. Coral reefs dominated by fleshy brown macroalgae have lower species richness and support lower levels of fishing and tourism than systems dominated by hard coral (Moberg \& Folke 1999). Intensive livestock grazing in Patagonia led to a transition from grasslands to shrublands, which increased evaporation and loss of water through deep drainage and decreased transpiration (Aguiar et al. 1996). Hysteresis can make it difficult for a system to shift back to its more desirable state (Scheffer et al. 1993). Hysteresis occurs when the restoration of the environmental conditions present before the regime shift is insufficient to restore the system to its previous state.

The variability of responses to environmental changes by species within a functional group (i.e., functionalresponse diversity) is thought necessary for resilience (Elmqvist et al. 2003; Chillo et al. 2011) because in ecosystems changing as a result of natural and human disturbance, ecological functions can be maintained despite the loss or decline of dominant species by functionally equivalent species that are less abundant (Walker et al. 1999; Chillo et al. 2011). However, as species within an ecosystem are extirpated or their abundances are greatly reduced, the diversity of ecological functions 
and of functional responses to disturbance is likely to decrease.

In addition to the diversity of functional responses, the distribution of functions within and across the scales of an ecosystem is thought to be a critical component of resilience (Peterson et al. 1998; Allen et al. 2005). If this is the case, then an assessment of resilience via the crossscale distribution of function may affect prioritization of species for conservation. Species that are charismatic, rare, or at greatest risk of extirpation or extinction may not contribute the most to ecological resilience. Allen et al. (2005) proposed measures of resilience at multiple scales that are an extension of the cross-scale resilience model (Peterson et al. 1998). To use these measures in an assessment of resilience, one must identify the aggregations and discontinuities in the distribution of body masses and quantify the functions provided by those species.

Ecological systems are structured by a few key processes that occur at distinct spatial extents and temporal frequencies, and these processes generate discontinuities in the spatial and temporal structure of landscapes and in the distribution of morphological features of species (Holling 1992). Ecological structure and resources are not distributed along continuous gradients; rather, they are characterized by domains of scale over which their distributions either do not change or change monotonically (Wiens 1989). Scale domains are separated by relatively nonlinear transitions from one set of dominant processes to another. Species interact with the environment as a function of their size (Woodward et al. 2005), so the pattern of scale domains and discontinuities in the physical environment ought to be reflected in animal body-mass distributions. Animal body-mass distributions consist of aggregations of similarly sized species that reflect a scale domain and gaps, or discontinuities, that reflect a transition to a new set of structuring processes (Holling 1992; Allen 2006; Fischer et al. 2008) (Table 1). It is possible that mechanisms of community assembly result in the partitioning of functions across scale domains to reduce competition among species and allow the coexistence of species that use similar resources (Peterson et al. 1998; Leyequien et al. 2007). If this is the case, a diversity of functions within an aggregation and a redundancy of functions across aggregations would increase ecological resilience because the loss of function in one aggregation would be compensated by one or more species from the same functional group that occurs within a different aggregation (Wardwell et al. 2008).

We analyzed the cross-scale resilience of a grassland avian community. We used 3 measures of cross-scale resilience, overall number of functional groups, number of functional groups within a body-size aggregation, and the redundancy of functional groups across aggregations, and tested the hypothesis that the local extinction of species is nonrandom with respect to the retention of functions.
Birds are clearly not the only taxonomic group that contributes to the resilience of grassland ecosystems, but they are useful subjects of analyses because data sets on birds are large and the information available regarding their presence and absence, diet, and foraging habits is of high quality.

\section{Methods}

The dry mixed grassland of southeastern Alberta (Canada) is one of the largest and most intact native grasslands remaining in the United States and Canada, where grasslands are one of the most threatened ecosystems (Samson \& Knopf 1994). Declines in grassland bird populations have been steeper and more widespread than those of any other avian guild in any other ecosystem in the United States and Canada (Vickery et al. 1999; Blancher 2003; Sauer et al. 2007). Eight-five percent of the species of birds designated as threatened by the government of Alberta occur in The Grassland Natural Region, of which the dry mixed grassland is 1 of 4 ecologically distinct subregions (Alberta Environment 2010) of Alberta. Of the roughly 5 million ha of dry mixed grassland, 54\% is native grassland (defined as quarter sections [approximately 65 ha] with $\geq 75 \%$ native vegetation) (Prairie Conservation Forum 2008).

Over $90 \%$ of the dry mixed grassland in Alberta is managed for livestock grazing and extensive agriculture. Grazing occurs on about $55 \%$ of the area, dry-land crops on about 35\%, and irrigated crops on about 10\% (Downing \& Pettapiece 2006). Hay is the primary dry-land crop, and it provides habitat for some grassland bird species. Grazing maintains the dry mixed grassland, and its positive and negative effects are more a function of grazing location, timing, and intensity than herbivory itself. Oil and gas exploration and extraction are manifest in extensive roads, well heads, and pipelines throughout the region. The number of natural gas wells drilled annually in Alberta increased 8-fold between 1990 and 2005, and the linear distance of natural gas pipeline increased roughly 4-fold (Canadian Association of Petroleum Producers 2008). The bulk of this development has occurred within the dry mixed grassland. In the future, the area of intensive agriculture may increase on lands currently used for extensive agriculture and oil, gas, and urban development may increase.

Historic drivers that shaped the dry mixed grassland were drought, grazing, and fire. Drought, rather than fire, is the primary driver maintaining the dry mixed grassland because it occurs more frequently than fire, inhibits expansion of woody shrubs, and prevents an accumulation of fuel that would maintain a frequent fire regime (Sala et al. 1996; Madden et al. 1999). Historical records suggest fire frequency in dry mixed grassland was 5-30 years, 
Table 1. Breeding birds associated with dry mixed grassland in Alberta (Canada), their status, functional-group membership, aggregation (cluster of similarly sized species) membership, and body mass.

\begin{tabular}{|c|c|c|c|c|c|}
\hline Common name & $\begin{array}{l}\text { Scientific } \\
\text { name }\end{array}$ & Status & $\begin{array}{l}\text { Functional } \\
\text { group }^{a}\end{array}$ & Aggregation & $\begin{array}{l}\text { Body mass } \\
(\log 10)^{b}\end{array}$ \\
\hline Yellow Warbler & Dendroica petechia & secure & arboreal invertivore & 1 & 0.983 \\
\hline Common Yellowthroat & Geothlypis trichas ${ }^{c}$ & threatened & terrestrial herbivore & 1 & 1.006 \\
\hline House Wren & Troglodytes aedon & secure & arboreal invertivore & 1 & 1.020 \\
\hline Least Flycatcher & Empidonax minimus ${ }^{c}$ & threatened & aerial invertivore & 1 & 1.025 \\
\hline Marsh Wren & Cistotborus palustris & secure & aquatic invertivore & 1 & 1.036 \\
\hline Brewer's Sparrow & Spizella breweri & secure & arboreal omnivore & 1 & 1.050 \\
\hline Black-capped Chickadee & Poecile atricapillus & secure & bark invertivore & 1 & 1.050 \\
\hline Clay-colored Sparrow & Spizella pallida ${ }^{c}$ & threatened & terrestrial herbivore & 1 & 1.058 \\
\hline Warbling Vireo & Vireo gilvus & secure & terrestrial herbivore & 1 & 1.082 \\
\hline Chipping Sparrow & Spizella passerina & secure & terrestrial omnivore & 1 & 1.094 \\
\hline Western Wood-Pewee & Contopus sordidulus ${ }^{c}$ & threatened & aerial invertivore & 1 & 1.121 \\
\hline Bank Swallow & Riparia riparia & secure & aerial invertivore & 1 & 1.139 \\
\hline Violet-green Swallow & Tachycineta thalassina & secure & aerial invertivore & 1 & 1.156 \\
\hline American Goldfinch & Carduelis tristis & secure & arboreal herbivore & 1 & 1.169 \\
\hline Lazuli Bunting & Passerina amoena & secure & arboreal omnivore & 1 & 1.177 \\
\hline $\begin{array}{l}\text { N. Rough-winged } \\
\text { Swallow }\end{array}$ & $\begin{array}{c}\text { Stelgidopteryx } \\
\text { serripennis }\end{array}$ & secure & aerial invertivore & 1 & 1.191 \\
\hline Rock Wren & Salpinctes obsoletus & secure & terrestrial invertivore & 2 & 1.223 \\
\hline Grasshopper Sparrow & $\begin{array}{l}\text { Ammodramus } \\
\text { savannarum }\end{array}$ & secure & terrestrial omnivore & 2 & 1.235 \\
\hline Red-eyed Vireo & Vireo olivaceus & secure & arboreal invertivore & 2 & 1.236 \\
\hline Savannah Sparrow & Passerculus wichensis & secure & terrestrial invertivore & 2 & 1.248 \\
\hline Barn Swallow & Hirundo rustica ${ }^{c}$ & threatened & aerial invertivore & 2 & 1.252 \\
\hline Baird's Sparrow & Ammodramus bairdii & secure & terrestrial omnivore & 2 & 1.279 \\
\hline $\begin{array}{l}\text { Chestnut-collared L } \\
\text { Ongspur }\end{array}$ & Calcarius ornatus & secure & terrestrial omnivore & 2 & 1.288 \\
\hline Tree Swallow & Tachycineta bicolor & secure & aerial invertivore & 2 & 1.326 \\
\hline Song Sparrow & Melospiza melodia ${ }^{c}$ & threatened & terrestrial omnivore & 2 & 1.334 \\
\hline House Finch & Carpodacus mexicanus & secure & terrestrial herbivore & 2 & 1.336 \\
\hline Cliff Swallow & $\begin{array}{l}\text { Petrocbelidon } \\
\text { pyrrbonota }\end{array}$ & secure & aerial invertivore & 2 & 1.364 \\
\hline Sprague's Pipit & Anthus spragueii ${ }^{d}$ & threatened & terrestrial invertivore & 2 & 1.372 \\
\hline Say's Phoebe & Sayornis saya & secure & aerial invertivore & 2 & 1.382 \\
\hline Vesper Sparrow & Pooecetes gramineus & secure & terrestrial omnivore & 2 & 1.408 \\
\hline Yellow-breasted Chat & Icteria virens & secure & arboreal invertivore & 2 & 1.411 \\
\hline McCown's Longspur & Calcarius mccownii & secure & terrestrial omnivore & 2 & 1.412 \\
\hline Downy Woodpecker & Picoides pubescens & secure & bark invertivore & 2 & 1.434 \\
\hline Lark Sparrow & Chondestes grammacus & secure & terrestrial omnivore & 2 & 1.459 \\
\hline Mountain Bluebird & Sialia currucoides & secure & aerial invertivore & 2 & 1.465 \\
\hline Veery & Catharus fuscescens & secure & terrestrial omnivore & 3 & 1.506 \\
\hline Bobolink & Dolichonyx oryzivorus & secure & arboreal omnivore & 3 & 1.517 \\
\hline Horned Lark & Eremophila alpestris & secure & terrestrial herbivore & 3 & 1.524 \\
\hline Cedar Waxwing & Bombycilla cedrorum & secure & arboreal omnivore & 3 & 1.530 \\
\hline Baltimore Oriole & Icterus galbula ${ }^{c}$ & threatened & aerial invertivore & 3 & 1.545 \\
\hline Gray Catbird & Dumetella carolinensis & secure & terrestrial omnivore & 3 & 1.563 \\
\hline Bullock's Oriole & Icterus bullockii & secure & arboreal invertivore & 3 & 1.574 \\
\hline Lark Bunting & $\begin{array}{l}\text { Calamospiza } \\
\text { melanocorys }\end{array}$ & secure & terrestrial omnivore & 3 & 1.578 \\
\hline Spotted Towhee & Pipilo maculatus & secure & terrestrial omnivore & 3 & 1.585 \\
\hline Western Kingbird & Tyrannus verticalis & secure & aerial invertivore & 3 & 1.611 \\
\hline Eastern Kingbird & Tyrannus tyrannus & secure & aerial invertivorel & 3 & 1.620 \\
\hline Sage Thrasher & Oreoscoptes montanus & threatened & terrestrial invertivore & 3 & 1.636 \\
\hline Brown-headed Cowbird & Molotbrus ater ${ }^{c}$ & threatened & terrestrial omnivore & 3 & 1.661 \\
\hline Spotted Sandpiper & Actitis macularius & secure & aquatic invertivore & 3 & 1.662 \\
\hline Black-headed Grosbeak & $\begin{array}{l}\text { Pheucticus } \\
\quad \text { melanocephalus }\end{array}$ & secure & arboreal omnivore & 3 & 1.667 \\
\hline Yellow-bellied Sapsucker & Spbyrapicus varius & secure & bark omnivore & 3 & 1.673 \\
\hline Loggerhead Shrike & Lanius ludovicianus $^{d}$ & threatened & aerial carnivore & 3 & 1.678 \\
\hline Northern Mockingbird & Mimus polyglottos & secure & terrestrial invertivore & 3 & 1.691 \\
\hline Piping Plover & Charadrius melodus $^{d}$ & threatened & aquatic invertivore & 3 & 1.734 \\
\hline
\end{tabular}


Table 1. (continued).

\begin{tabular}{|c|c|c|c|c|c|}
\hline Common name & $\begin{array}{l}\text { Scientific } \\
\text { name }\end{array}$ & Status & $\begin{array}{l}\text { Functional } \\
\text { group }^{a}\end{array}$ & Aggregation & $\begin{array}{l}\text { Body mass } \\
(\log 10)^{b}\end{array}$ \\
\hline Wilson's Phalarope & Pbalaropus tricolor & secure & aquatic invertivore & 4 & 1.782 \\
\hline Red-winged Blackbird & Agelaius phoeniceus $^{c}$ & threatened & terrestrial omnivore & 4 & 1.812 \\
\hline Northern Shrike & Lanius excubitor & secure & aerial carnivore & 4 & 1.815 \\
\hline Brewer's Blackbird & $\begin{array}{l}\text { Euphagus } \\
\text { cyanocephalus }\end{array}$ & secure & terrestrial invertivore & 4 & 1.837 \\
\hline Brown Thrasher & Toxostoma rufum ${ }^{c}$ & threatened & terrestrial omnivore & 4 & 1.840 \\
\hline Hairy Woodpecker & Picoides villosus & secure & bark invertivore & 4 & 1.857 \\
\hline Common Nighthawk & Chordeiles minor ${ }^{d}$ & threatened & aerial invertivore & 4 & 1.881 \\
\hline Sora & Porzana carolina ${ }^{c}$ & threatened & aquatic herbivore & 4 & 1.885 \\
\hline American Robin & Turdus migratorius & secure & arboreal omnivore & 4 & 1.894 \\
\hline Yellow-headed Blackbird & $\begin{array}{l}\text { Xanthocephalus } \\
\text { xantbocephalus }^{b}\end{array}$ & threatened & terrestrial omnivore & 4 & 1.928 \\
\hline Killdeer & Charadrius vociferus $^{c}$ & threatened & terrestrial invertivore & 4 & 1.959 \\
\hline Mountain Plover & Charadrius montanus $^{d}$ & threatened & terrestrial invertivore & 4 & 1.980 \\
\hline American Kestrel & Falco sparverius & secure & aerial carnivore & 4 & 1.987 \\
\hline Wilson's Snipe & Gallinago delicata & secure & terrestrial invertivore & 4 & 1.994 \\
\hline Western Meadowlark & Sturnella neglecta & secure & terrestrial invertivore & 5 & 2.040 \\
\hline Common Grackle & Quiscalus quiscula ${ }^{c}$ & threatened & terrestrial omnivore & 5 & 2.067 \\
\hline Mourning Dove & Zenaida macroura & secure & terrestrial herbivore & 5 & 2.090 \\
\hline Northern Flicker & Colaptes auratus & secure & terrestrial invertivore & 5 & 2.166 \\
\hline Belted Kingfisher & Megaceryle alcyon & secure & aquatic carnivore & 5 & 2.167 \\
\hline Burrowing Owl & Athene cunicularia ${ }^{d}$ & threatened & aerial carnivore & 5 & 2.173 \\
\hline Merlin & Falco columbarius & secure & aerial carnivore & 5 & 2.191 \\
\hline Upland Sandpiper & Bartramia longicauda & secure & terrestrial invertivore & 5 & 2.200 \\
\hline Black-necked Stilt & Himantopus mexicanus & secure & aquatic invertivore & 5 & 2.229 \\
\hline Black-billed Magpie & Pica budsonia & secure & terrestrial omnivore & 5 & 2.281 \\
\hline Long-eared Owl & Asio otus & secure & aerial carnivore & 6 & 2.350 \\
\hline Willet & Tringa semipalmata & secure & aquatic carnivore & 6 & 2.433 \\
\hline Pileated Woodpecker & Dryocopus pileatus & secure & bark invertivore & 6 & 2.474 \\
\hline Short-eared Owl & Asio flammeus $^{d}$ & threatened & aerial carnivore & 6 & 2.480 \\
\hline American Avocet & $\begin{array}{c}\text { Recurvirostra } \\
\text { americana }\end{array}$ & secure & aquatic omnivore & 6 & 2.505 \\
\hline Marbled Godwit & Limosa fedoa & secure & aquatic omnivore & 6 & 2.548 \\
\hline Cooper's Hawk & Accipiter cooperii & secure & aerial carnivore & 6 & 2.585 \\
\hline Northern Harrier & Circus cyaneus & secure & aerial carnivore & 6 & 2.656 \\
\hline American Crow & Corvus brachyrbynchos & secure & terrestrial omnivore & 7 & 2.703 \\
\hline White-faced Ibis & Plegadis chibi & secure & aquatic carnivore & 7 & 2.784 \\
\hline Long-billed Curlew & Numenius americanus & secure & terrestrial carnivore & 7 & 2.812 \\
\hline American Bittern & Botaurus lentiginosus ${ }^{c}$ & threatened & aquatic carnivore & 7 & 2.862 \\
\hline Sharp-tailed Grouse & $\begin{array}{l}\text { Tympanuchus } \\
\text { phasianellus }\end{array}$ & secure & terrestrial herbivore & 7 & 2.907 \\
\hline Swainson's Hawk & Buteo swainsoni & secure & aerial carnivore & 7 & 2.921 \\
\hline $\begin{array}{l}\text { Black-crowned } \\
\text { Night-Heron }\end{array}$ & Nycticorax nycticorax & secure & aquatic carnivore & 7 & 2.929 \\
\hline Prairie Falcon & Falco mexicanus & secure & aerial carnivore & 7 & 2.955 \\
\hline Red-tailed Hawk & Buteo jamaicensis & secure & aerial carnivore & 7 & 2.962 \\
\hline Great Horned Owl & Bubo virginianus & secure & aerial carnivore & 8 & 3.122 \\
\hline Ferruginous Hawk & Buteo regalis ${ }^{d}$ & threatened & aerial carnivore & 8 & 3.177 \\
\hline Turkey Vulture & Catbartes aura & secure & aerial carnivore & 8 & 3.296 \\
\hline Great Blue Heron & Ardea berodias & secure & aquatic carnivore & 8 & 3.329 \\
\hline Greater Sage-Grouse & $\begin{array}{l}\text { Centrocercus } \\
\text { urophasianus }^{a}\end{array}$ & threatened & terrestrial herbivore & 8 & 3.385 \\
\hline Golden Eagle & Aquila chrysaetos & secure & aerial carnivore & 8 & 3.602 \\
\hline
\end{tabular}

${ }^{a}$ Functional groups are a combination of dietary and foraging strategy.

${ }^{b}$ Average adult male and female masses.

'Species classified as threatened on the basis of significant ( $\mathrm{p}<0.05)$ decline in abundance in Breeding Bird Survey data from $1966-2007$ (Sauer et al. 2007).

${ }^{d}$ Species classified as threatened by the government of Alberta or government of Canada. 
whereas it was 5-10 years in mixed-grass land (Madden et al. 1999; Truett 2003). In the past, bison (Bison bison) and other ungulates, such as pronghorn (Antilocapra americana), grazed the region, and to a certain extent bison grazing has been replaced by cattle grazing. Because there are substantial differences in the ecological roles of bison and cattle, the ability of cattle to functionally replace bison remains uncertain.

We compiled a list of breeding birds that occur in the dry mixed-grass land from Alberta government data (Banasch \& Samuel 1998; Dale et al. 1999; Knapton et al. 2005; Gutsell et al. 2005a, 2005b), the North American Breeding Bird Survey (BBS) (Sauer et al. 2007), the Audubon Christmas Bird Count (National Audubon Society 1983-2005), the Royal Alberta Museum, and the Federation of Alberta Naturalists (Penner, personal communication). We assigned each species to a functional group (Table 1) on the basis of its dietary strategy and foraging strategy (Poole 2006). We defined dietary strategies--carnivore, herbivore, invertivore, and omnivore-on the basis of the type of food items eaten during the breeding season. A species was considered an omnivore if its diet included a minimum of $30 \%$ of both plants and animals. Foraging strategies were aerial; arboreal or foliage; aquatic; bark; and terrestrial. Our categories are coarse, but match the generality of the ecological questions we addressed.

We identified the scale domains at which species are distributed by rank ordering species by their log body mass and analyzing whether body-mass distributions were discontinuous. We calculated body mass by averaging adult male and female body-mass data from the Royal Alberta Museum specimen database. If the sample size from the museum was $<30$, we used data from published studies conducted in similar ecosystems in the United States and Canada. It is recommended that several statistical methods be used to identify discontinuities in body-mass distributions and then that one assess whether the results converge (Stow et al. 2007). We used the analytical methods of Bayesian classification and regression tree (BCART) (Breiman et al. 1984) and the gap rarity index (Restrepo et al. 1997).

We used 3 measures of cross-scale resilience: number of functional groups; number of functional groups within each body-mass aggregation; and number of body-mass aggregations in which each functional group is present (Allen et al. 2005). We calculated values for all 3 measures for the complete data set (101 species). Then we removed all threatened species (25) from the data set to simulate their extirpation from the system and recalculated values for the 3 measures.

We categorized species as secure or threatened. Species were categorized as threatened if either the provincial or federal government listed a species as endangered or threatened or if BBS data for Alberta showed a significant $(\phi<0.05)$ (Sauer et al. 2007), decline in abundance from (1966-2007) (15 species). A threatened categorization reflected probability of regional extirpation, not global extinction. We also used BBS trend data to categorize species as threatened because governmental endangered species listings can be controversial and affected by political considerations. The BBS data alone were not considered adequate for categorization because surveys are conducted along roadsides and likely underdetect wary and wetland birds, birds with small populations, or birds with habitats that occur primarily away from roads (Sauer et al. 2007).

We compared the observed loss of threatened species with simulated random loss to determine whether species extinctions were nonrandom with respect to the retention of function. Random loss of species was simulated in a Monte Carlo process in Matlab (5000 iterations). We fixed the number of aggregations and the number of species in each aggregation to be equivalent to the number of aggregations and species in the observed data, but the selection of which 25 species were removed was randomized. We calculated values of the 3 measures for each iteration and then created a distribution of values for each measure. We ranked our observed results within the random distributions generated by the Monte Carlo simulations. The ranking of the observed data within the distributions generated by the simulation provided a probability that the observed results were the result of a random process. We further used this probability to determine whether each observed result was in the lower or upper half of the random distribution. We applied a binomial test to determine whether the preponderance of our within- and across-aggregation functional-group observations were randomly or nonrandomly distributed within the Monte Carlo simulations.

\section{Results}

The breeding bird community of the dry mixed grassland consisted of 101 species from 15 functional groups and included wetland songbirds and waders. We did not include 33 deepwater species in our analyses because they have different body-mass distributions than terrestrial species and the mechanisms driving aquatic body masses are not well understood (Holling 1992). There were 8 body-mass aggregations (Table 1 ). The number of functional groups represented within each aggregation ranged from 3 to 9. The aggregations of smaller-bodied birds included more species and functional groups. The aggregations of larger-bodied species had substantially fewer species and fewer functional groups.

The redundancy of function across aggregations was phylogenetically constrained. For example, there were no small aerial carnivores or aquatic carnivores, and there were no large aerial invertivores or arboreal invertivores. 
Of the 15 functional groups, 3 occurred in 6 aggregations, 5 functional groups had one representative and occurred in only one aggregation, and the remaining 7 functional groups occurred in 3-4 aggregations.

The distribution of functions after removing the 25 threatened species from the data set suggested that the distribution of function within and across aggregations was highly conserved despite the high number of potential extinctions because the 3 measures of resilience were relatively unchanged. Overall number of functional groups was reduced from 15 to 14 due to the extinction of the Sora (Porzana carolina), the sole aquatic herbivore. The loss of functional diversity within aggregations was minimal. Aggregation 4 lost the most species (Brown Thrasher [Toxostoma rufum], Common Nighthawk [Chordeiles minor], Killdeer [Charadrius vociferous], Mountain Plover [Charadrius montanus], Red-winged Blackbird [Agelaius pboeniceus], Sora, and Yellow-headed Blackbird [Xantbocephalus xantbocephus]), but despite the loss of 7 species, 5 of the 8 functional groups in the aggregation remained.

The redundancy of functional groups across aggregations was also strongly retained, despite the extinction of $25 \%$ of species. Only 1 functional group (aquatic herbivore) was extirpated entirely, although 5 functional groups had only 1 representative initially. The functional group terrestrial herbivores had the greatest reduction in representation across aggregations, from 6 to 3 .

Values of the 3 measures of function did not change substantially in response to extinctions of $25 \%$ of the species. For example, 7 of 8 functional groups remained in aggregation 1, aggregation 2 retained 6 of 6 functional groups, and 8 of 9 functional groups remained in aggregation 3. Although the overall distribution of function within and across the aggregations did not change substantially, despite the extinctions, resilience was reduced because the number of species that represented a functional group within an aggregation was greatly reduced. For example, when we counted the number of species per functional group per aggregation, 58\% of the time a functional group within an aggregation was represented by one species. Aggregation 5 had 6 functional groups before and after the threatened species were removed. However, 5 of those functional groups were represented by only one species following extinctions. Further losses in that aggregation would result in reduced functional diversity at that aggregation and in a reduced redundancy of function across aggregations.

Given the uncertainty associated with response diversity within functional groups, we suggest a particular body-mass aggregation may not be resilient to disturbances when there are $\leq 2$ species per functional group. Disturbances are often scale specific, and although functionally similar species in different aggregations can theoretically compensate for the loss of function in another aggregation, morphologically imposed foraging constraints can prevent true replacement. Therefore, we once again counted the number of species per functional group per aggregation, but this time calculated the number of times 1 or 2 species remained as the sole representatives of a functional group within that aggregation. Seventy-four percent of the time a functional group within an aggregation was represented by only 1 or 2 species following extinctions, and $80 \%$ of the time the redundancy of function across aggregations was reduced to 1 or 2 species. The fact that any additional bird extinctions have a high probability of eliminating a functional group within a particular scale domain indicates the resilience of the grassland, as represented by the distribution pattern of the breeding birds, may have been reduced. Of the 3 measures, number of functional groups was the least affected by future extinctions. Ten of the 15 functional groups had 3 or more species remaining, so future extinctions would initially have a smaller effect on number of functional groups than they would on the other 2 measures of resilience.

We also compared the observed distribution of function remaining after the extinction of the threatened species with the 5000 simulations of the null model of random species removals. The comparison of observed and expected results for the within-aggregation functional diversity showed that 5 of 8 aggregations retained a greater number of functional groups than expected (binomial $p$ $=0.22$ ). Ten of the 15 functional groups were represented in more aggregations than expected (binomial $p$ $=0.09$ ) (Table 2 ). The probability of the observed results for all 3 measures of functionality was 0.08 . The distribution of function within and across scales was retained at higher than expected values and was consistent with the hypothesis that species extinctions are nonrandom.

\section{Discussion}

Our results are consistent with the hypothesis that functions are distributed in a manner expected to contribute to resilience and that this distribution pattern is maintained even with the extinction of species. This distribution pattern is explained in part by phylogeny. Macroevolutionary processes affect which species are available to colonize a particular ecosystem, but mesoscale processes of niche exploitation and competition drive the observed pattern of functional distribution within and across the scales in an ecosystem (Allen et al. 2006). The observed pattern of extinction of 25 species compared with the random removal of 25 species also suggests that species' extinctions are nonrandom because the cross-scale distribution of function remained intact, especially compared with the distribution of function following random extinction. Although the results of a variety of studies show species extinctions are nonrandom with respect to 
Table 2. Ranking (i.e., upper or lower half of the distribution resulting from the output of $\mathbf{5 0 0 0}$ iterations of a Monte Carlo simulation) of observed number of functional groups, number of functional groups within each body-mass aggregation, and number of body-mass aggregations in which a functional group is present for birds associated with the dry mixed grassland in Alberta (Canada).

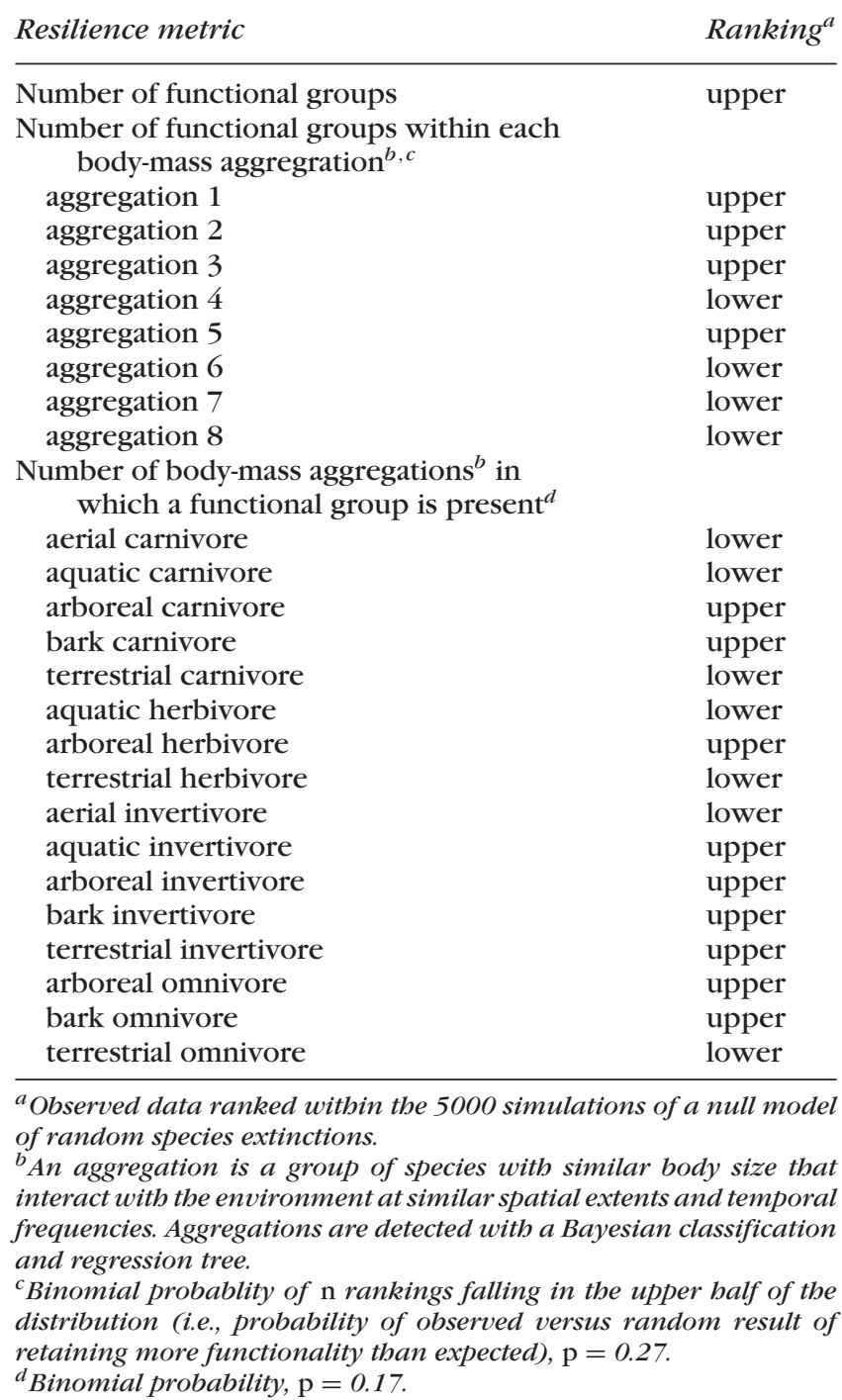

phylogeny (von Euler 2001; Rezende et al. 2007), communities with and without compensatory mechanisms (Kremen 2005), and the order of extinctions (Larsen et al. 2005), we are the first to demonstrate that the distribution of functions within and across scales may contribute to a nonrandom extinction process.

We hypothesized that the extinction of one species within a functional group may reduce competition among other species with similar diets and foraging strategies and increase their ability to survive future disturbances. Results of studies of food-web networks suggest that nonrandom extinctions can allow communities to retain resilience to disturbances because surviving species will have greater average resilience as the number of their competitors decreases (Ives \& Cardinale 2004).
In our study, threatened species accounted for $25 \%$ of the number of bird species, yet even with their hypothetical loss the ecosystem retained almost complete functionality on the basis of the 3 cross-scale resilience measures. However, the loss of species decreases diversity of responses to disturbance, cross-scale redundancy of function, and within-scale diversity of function and may compromise resilience. Should the threatened species become extinct, the grassland would be at a threshold at which the loss of virtually any additional species would result in a reduction in functional diversity within scales and in functional redundancy across scales.

Peterson et al. (1998) suggest that functions will be more diverse within a body-size aggregation and more evenly distributed across aggregations as a result of community assembly mechanisms that partition species that forage on similar resources (analogous here to providing similar functions). The consequence of this distribution is a more stable provision of functions in the face of disturbances and losses of species within particular aggregations. Relatively intact systems, such as our study area, can support high levels of losses without a substantial reduction in function. However, the loss of entire functional groups can decrease grassland resilience to colonization by non-native species (Zavaleta \& Hulvey 2004).

The dry mixed-grass land is considered relatively intact in part because there has been little outright loss due to urbanization. Although the spatial and temporal pattern of disturbance processes has changed over the last century, ranchers are encouraged to graze their cattle in a heterogeneous pattern to mimic bison grazing patterns, and fires, although infrequent, are not always easily suppressed despite fire suppression being standard practice ( $T$. Kupchenko, personal communication). Insofar as extinctions and successful colonization by nonnative species reflect the degree of habitat change in a landscape, among avian species only the Greater PrairieChicken (Tympanuchus cupido pinnatus) and Passenger Pigeon (Ectopistes migratorius) have become extinct since precolonial times, and only 5 species have established breeding populations: House Sparrow (Passer domesticus), European Starling (Sturnus vulgaris), Rock Pigeon (Columbia livia), Gray Partridge (Perdix perdix), and Ring-necked Pheasant (Phasianus colchicus). Most agriculture is extensive, so gross grassland characteristics remain, despite the loss of some native species to non-native grasses.

In the dry mixed grassland, the extinction of avian species would directly reduce the distribution of function within and across aggregations, and insofar as birds play a functional role in maintaining the dominance of grasses, the loss of further species could increase the probability of a regime shift. This is analogous to foodweb studies in which stability decreases as the number of 
links (species) decreases (Dunne et al. 2002). Food webs have thresholds of node loss beyond which the network can collapse (Dunne et al. 2002). Although bison and other species may have historically been stronger drivers of plant structure and composition in the dry mixed grassland than birds, the fact that the grassland has persisted despite the extinction or decreased abundance of some species suggests that other species have compensated functionally.

There are some weaknesses to our methods. Current strategies for categorizing species into functional groups are unsatisfactory because it would be difficult to explicitly link a functional group to ecosystem processes. It is challenging to develop functional categories appropriate to the scale and goals of a study. We included within our study assemblage all native breeding birds in the grassland, including grassland obligates and species that breed in riparian shrubs and trees, cliffs, sand dunes, and other features common to the ecosystem. Thus, although species may belong to the same functional group and be in different body-mass aggregations, the degree to which one species can functionally compensate for another may be restricted by the ecological niche it occupies within the grassland. Also, the grassland breeding birds are only part of the plant and animal assemblage that contributes to the processes and functions of the grassland, and the extinction of a bird species will affect and be affected by the other biotic and abiotic elements with which it interacts.

Maintaining within-scale functional diversity and crossscale functional redundancy is a hedge against the uncertainty and unpredictability inherent in nonlinear complex systems with multiple alternative regimes (Scheffer \& Carpenter 2003; Kinzig et al. 2006). Resilience, as quantified by the distribution of functions, could be a tool for objectively assessing species' ecological importance if the focus is system behavior and persistence. We believe stronger empirical links need to be made between functional classifications and ecosystem processes. However, until the complex dynamics governing nonlinear shifts in ecosystem structure and processes are better understood, maintaining functional diversity within and across scales may prevent transitions to alternative regimes.

\section{Acknowledgments}

S. M.S. was supported by a National Sciences and Engineering Research Council Canada Graduate Scholarship grant. C.R.A. was supported by a 21st Century Research Award-Studying Complex Systems from the James S. McDonnell Foundation. The Nebraska Cooperative Fish and Wildlife Research Unit is jointly supported by a cooperative agreement between the U.S. Geological Survey, the Nebraska Game and Parks Commission, the University of Nebraska-Lincoln, the U.S. Fish and Wildlife Service, and the Wildlife Management Institute. Any use of trade names is for descriptive purposes only and does not imply endorsement by the U.S. Government. C.B. was funded by the Andrew W. Mellon Foundation.

\section{Literature Cited}

Aguiar, M. R., J. M. Paruclo, O. E. Sala, and W. K. Lauenroth. 1996. Ecosystem responses to changes in plant functional type composition: an example from the Patagonian Steppe. Journal of Vegetation Science 7:381-390.

Alberta Environment. 2010. The general status of Alberta wild species. Alberta Sustainable Resource Development, Edmonton.

Allen, C. R., A. S. Garmestani, T. D. Havlicek, P. A. Marquet, G. D. Peterson, C. Restrepo, C. A. Stow, and B. E. Weeks. 2006. Patterns in body mass distributions: sifting among alternative hypotheses. Ecology Letters 9:630-643.

Allen, C. R. 2006. Discontinuities in ecological data. Proceedings of the National Academy of Sciences 103:6083-6084.

Allen, C. R., L. Gunderson, and A. R. Johnson. 2005. The use of discontinuities and functional groups to assess relative resilience in complex systems. Ecosystems 8:958-966.

Banasch, U., and B. Samuel. 1998. Raptor component report. Canadian Wildlife Service, Alberta, Edmonton.

Bellwood, D. R., T. P. Hughes, C. Folke, and M. Nystrom. 2004. Confronting the coral reef crisis. Nature 429:827-833

Blancher, P. 2003. Importance of North America's grasslands to birds. Commission for Environmental Cooperation, Montreal.

Breiman, L., J. H. Friedman, R. A. Olshen, and C. J. Stone. 1984. Classification and regression trees. Wadsworth International Group, Belmont, California.

Canadian Association of Petroleum Producers (CAPP). 2008. CAPP statistical handbook. CAPPCalgary, Alberta. Available from http://www.capp.ca/library/statistics/handbook (accessed 2008).

Chapin, F. S. et al. 2000. Consequences of changing biodiversity. Nature 405:234-242.

Chillo, V., M. Ananad, and R. A. Ojeda. 2011. Assessing the use of functional diversity as a measure of ecological resilience in arid rangelands. Ecosystems 14:1168-1177.

Dale, B., P. Taylor, and J. P. Goossen. 1999. Avifauna component report. Canadian Wildlife Service, Alberta, Edmonton.

Downing, D. J., and W. W. Pettapiece. 2006. Natural regions and subregions of Alberta. Publication T/852. Government of Alberta, Edmonton.

Dunne, J. A., R. J. Williams, and N. D. Martinez. 2002. Network structure and biodiversity loss in food webs: robustness increases with connectance. Ecology Letters 5:558-567.

Elmqvist, T., C. Folke, M. Nystrom, G. Peterson, J. Bengtsson, B. Walker, and J. Norberg. 2003. Response diversity, ecosystem change, and resilience. Frontiers in Ecology 1:488-494.

Fischer, J., D. B. Lindenmayer, and R. Montague-Drake. 2008. The role of landscape texture in conservation biology: a case study on birds in south-eastern Australia. Diversity and Distributions 14:3846.

Folke, C., S. Carpenter, B. Walker, M. Scheffer, T. Elmqvist, L. Gunderson, and C. S. Holling. 2004. Regime shifts, resilience, and biodiversity in ecosystem management. Annual Review of Ecology, Evolution and Systematics 35:557-581.

Gutsell, R., S. Cotterill, and C. Platt. 2005 $a$. Preliminary status evaluation of the birds: passerines. Alberta Sustainable Resource Development, Edmonton.

Gutsell, R., S. Feser, S. Cotterill, and C. Platt. 2005b. Preliminary status evaluation of the birds: non-passerines. Alberta Sustainable Resource Development, Edmonton.

Holling, C. S. 1973. Resilience and stability of ecological systems. Annual Review of Ecology and Systematics 4:1-23. 
Holling, C. S. 1992. Cross-scale morphology, geometry, and dynamics of ecosystems. Ecological Monographs 62:447-502.

Hooper, D. and P. M. Vitousek. 1997. The effects of plant composition and diversity on ecosystem processes. Science 277:1302-1305. .

Hughes, T. 1994. Catastrophes, phase shifts, and large-scale degradation of a Caribbean coral reef. Science 265:1547-1551.

Ives, A. R., and B. J. Cardinale. 2004. Food-web interactions govern the resistance of communities after non-random extinctions. Nature 429:174-177.

Kinzig, A. P., P. R. Ryan, M. Etienne, H. Allison, T. Elmqvist, and B. H. Walker. 2006. Resilience and regime shifts: assessing cascading effects. Ecology and Society 11:363-385.

Knapton, R. W., G. L. Holroyd, and H. E. Trefry. 2005. Vertebrate species at risk at Onefour research sub-station. Environment Canada, Alberta, Edmonton.

Kremen, C. 2005. Managing ecosystem services: What do we need to know about their ecology? Ecology Letters 8:468-479.

Larsen, T. H., N. M. Williams, and C. Kremen. 2005. Extinction order and altered community structure rapidly disrupt ecosystem functioning. Ecology Letters 8:538-547.

Leyequien, E., W. F. de Boer, and A. Cleef. 2007. Influence of body size on coexistence of bird species. Ecological Research 22:735-741.

Madden, E. M., A. J. Hansen, and R. K. Murphy. 1999. Influence of prescribed fire history on habitat and abundance of passersine birds in northern mixed-grass prairie. The Canadian Field-Naturalist 113:627-640.

Moberg, F., and C. Folke. 1999. Ecological goods and services of coral reef systems. Ecological Economics 29:215-233.

Mumby, P. J., A. Hastings, and H. J. Edwards. 2007. Thresholds and the resilience of Caribbean coral reefs. Nature 450:98-101.

National Audubon Society. 1983-2005. The Christmas Bird Count historical results. National Audubon Society, New York. Available from http://www.audubon.org/bird/cbc (accessed June 2006).

Nystrom, M. 2006. Redundancy and response diversity of functional groups: implications for the resilience of coral reefs. Ambio 35:30-35.

Peterson, G., C. R. Allen, and C. S. Holling. 1998. Ecological resilience, biodiversity, and scale. Ecosystems 1:6-18.

Poole, A. editor. 2006. The birds of North America online. Cornell Laboratory of Ornithology, Ithaca, New York. Available from http://bna.birds.cornell.edu/BNA (accessed 2006).

Prairie Conservation Forum. 2008. Native prairie vegetation baseline inventory for the Grassland Natural Region of Alberta. Prairie Conservation Forum, Lethbridge, Alberta. Available from http://www.albertapfc.org (accessed August 2008).

Restrepo, C., L. M. Renjifo, and P. Marples. 1997. Frugivorous birds in fragmented Neotropical montane forests: landscape pattern and body mass distribution. Pages 171-189 in W. F. Laurance, R. O. Bierregaard, and C. Moritz, editors. Tropical forest remnants: ecology, management and conservation of fragmented communities. University of Chicago Press, Chicago.
Rezende, E. L., J. E. Lavabre, P. R. Guimaraes Jr., P. Jordano, and J. Bascompte. 2007. Non-random coextinctions in phylogenetically structured mutualistic networks. Nature 448:925-928.

Sala, O. E., W. K. Lauenroth, S. J. McNaughton, G. Rusch, and X. Shang. 1996. Biodiversity and ecosystem functioning in grasslands. Pages 129-149 in H. A. Mooney, J. H. Cushman, E. Medina, O. E. Sala, and E. D. Schulze, editors. Functional roles of biodiversity: a global perspective. John Wiley \& Sons, Chichester.

Samson, F. B., and F. L. Knopf. 1994. Prairie conservation in North America. BioScience 44:418-421.

Sauer, J. R., J. E. Hines, and J. Fallon. 2007. North American Breeding Bird Survey, results and analysis 1966-2006. U.S. Geological Survey, Patuxent Wildlife Research Center, Patuxent, Maryland. Available from http://www.pwrc.usgs.gov/bbs (accessed 2007).

Scheffer, M., S. H. Hosper, M. L. Meijer, and B. Moss. 1993. Alternative equilibria in shallow lakes. Trends in Ecology \& Evolution 8:275-279.

Scheffer, M., and S. R. Carpenter. 2003. Catastrophic regime shifts in ecosystems: Linking theory to observation. Trends in Ecology \& Evolution 18:648-656.

Silver, W. L., S. Brown, and A. E. Lugo. 1996. Effects of changes in biodiversity on ecosystem function in tropical rainforests. Conservation Biology 10:17-24.

Stow, C., C. R. Allen, and A. S. Garmestani. 2007. Evaluating discontinuities in complex systems: toward quantitative measures of resilience. Ecology and Society 12:26.

Truett, J. C. 2003. Migrations of grassland communities and grazing philosophies in the Great Plains: a review and implications for management. Great Plains Research 13:3-26.

Vickery, P. D., P. L. Tubaro, J. M. C. DaSilva, B. G. Peterjohn, J. R. Herkert, and R. B. Cavalcanti. 1999. Ecology and conservation of grassland birds in the Western Hemisphere. Studies in avian biology. Number 19. Cooper Ornithological Society, Waco, Texas.

von Euler, F. 2001. Selective extinction and rapid loss of evolutionary history in the bird fauna. Proceedings of the Royal Society of London B 268:127-130.

Walker, B., A. Kinzig, and J. Langridge. 1999. Plant attribute diversity, resilience, and ecosystem function: the nature and significance of dominant and minor species. Ecosystems 2:95-113.

Wardwell, D. A., C. R. Allen, G. D. Peterson, and A. J. Tyre. 2008. A test of the cross-scale resilience model: functional richness in Mediterreanean-climate ecosystems. Ecological Complexity 5:165-182.

Wiens, J. A. 1989. Spatial scaling in ecology. Functional Ecology 4:385-397.

Woodward, G., B. Ebenman, M. Emmerson, J. M. Montoya, J. M. Olesen, A. Valido, and P. H. Warren. 2005. Body size in ecological networks. Trends in Ecology \& Evolution 20:402-409.

Zavaleta, E. S., and K. B. Hulvey. 2004. Realistic species losses disproportionately reduce grassland resistance to biological invaders. Science 306:1175-1177. 